Article

\title{
The Effect of Cropping Method and Botanical Form on Seed Yielding and Chemical Composition of Chickpeas (Cicer arietinum L.) Grown under Organic System
}

\author{
Jerzy Księżak and Jolanta Bojarszczuk * \\ Department of Forage Crop Production, Institute of Soil Science and Plant Cultivation-State Research Institute \\ in Puławy, Czartoryskich Street 8, 24-100 Puławy, Poland; jksiezak@iung.pulawy.pl \\ * Correspondence: jbojarszczuk@iung.pulawy.pl; Tel.: +48-81-478-67-96
}

Received: 8 May 2020; Accepted: 29 May 2020; Published: 4 June 2020

check for updates

\begin{abstract}
A field study was conducted at the Agricultural Experimental Station in Grabów in Poland between 2017-2018. This study evaluated seed yield and chemical composition of chickpeas (Cicer arietinum L.) under organic conditions, either growing as a sole crop, or with barley (Hordeum vulgare) or oats (Avena sativa L.) as supporting plants. Two chickpea types were included in experiment scheme: kabuli and desi. The experiment was established as a split-plot design with four replicates. The study showed that a higher total seed yields of both forms of chickpeas grown in both pure sowing and with spring cereals was obtained in 2018 than 2017. The higher yield in this study period was the result of a greater number of pods, seeds, and higher weight of the chickpea seed and cereal grains on a plant. Higher yields were noted in chickpeas grown with supporting crops than in sole cropping. Significantly better thousand seed weight of both botanical forms of chickpeas was observed in chickpeas grown in sole cropping than with supporting plants. Regardless of cropping method, the desi form was characterized by higher yields than the kabuli type, and its percentage in seed yields of chickpeas grown with cereals was higher than the kabuli type. The highest seed yields were obtained in chickpeas grown with oats. Neither chickpea type had a significant effect on the height of cereal plant, the number of grains on each plant, the number of producing shoots or thousandgrainweight of the two cereal species. Regardless of cropping method, the highest content of fiber and fat was determined in desi-type seeds, while the highest protein and phosphorus content was characterized kabuli-type seeds.
\end{abstract}

Keywords: evaluation; sole cropping; supporting plant; desi; kabuli; organic farming

\section{Introduction}

The chickpea (Cicer arietinum L.) is one of the oldest and valued crops and provides nutritious food for an expanding world population and will become increasingly important with climate change [1]. Land area devoted to chickpea has increased in recent 10 years by about $17 \%$ and now stands at an estimated 14.56 million hectares [2]. Its cultivation is popular in countries with small rainfall [3,4].

Chickpea is grown all over the world in about 57 countries under varied environmental conditions, particularly on the Indian Peninsula, in the Mediterranean, Australia, Africa, South and North America, the Balkans and Slovakia, Pakistan, Syria, Tunisia [1,5-7]. South and South-East Asia dominates in chickpea production with $80 \%$ of regional contribution. Although developed countries do not contribute much toward chickpea production, the yield is particularly high in some Eastern European countries. Worldwide, chickpea ranks third among the pulse crops. An average yield of chickpeas is $849 \mathrm{~kg} \cdot \mathrm{ha}^{-1}$ [2]. There are two distinct types of cultivated chickpea: desi and kabuli. The desi 
types have pink flowers, anthocyanin pigmentation on stems. The kabuli types have white flowers, lack anthocyanin pigmentation on stems, and have white or beige-colored seeds with a ram's head shape [8]. The desi types account for about $80-85 \%$ of the total chickpea area and are mostly grown in Asia and Africa [9]. The kabuli types are largely grown in West Asia, North Africa, North America and Europe. The seed weight generally ranges from 0.1 to $0.3 \mathrm{~g}$ and 0.2 to $0.6 \mathrm{~g}$ in the desi and kabuli types, respectively [10]. Desi chickpeas have a thicker testa, accounting for $150 \mathrm{~g} \cdot \mathrm{kg}^{-1} \mathrm{dry}$ weight as compared with $70 \mathrm{~g} \cdot \mathrm{kg}^{-1}$ in kabuli chickpeas, which affects the determination of seed composition [11].

Chickpea seeds are large in size, salmon-white in color and contain high levels of carbohydrate (41.1-47.4\%) and protein (21.7-23.4\%). The protein content (22.9-24.8\%) of chickpeas was much higher than that of cereals (wheat and maize) and comparable to other legumes [11]. Protein concentration generally varies by only a small magnitude between desi and kabuli market classes. Chickpea protein concentration ranges from 160 to $300 \mathrm{~g} \cdot \mathrm{kg}^{-1}$ and from 120 to $290 \mathrm{~g} \cdot \mathrm{kg}^{-1}$ for desi and kabuli market classes, respectively [10]. Mineral composition of chickpeas cultivars showed that they contribute sufficient amount of $\mathrm{Ca}, \mathrm{P}, \mathrm{K}, \mathrm{Cu}, \mathrm{Zn}$ and $\mathrm{Mg}$ in human diets to meet the recommended dietary allowance $[5,12,13]$. Chickpea is a good source of carbohydrates and protein, together constituting about $80 \%$ of the total dry seed mass [14] in comparison with other pulses. Starch is the major carbohydrate fraction, representing about $83.9 \%$ of the total carbohydrates [15]. Chickpea is cholesterol free and is a good source of dietary fiber, vitamins and minerals [11].

Chickpea is consumed as whole seed, dhal (decorticated splitcotyledons) or dhal flour [10]. In organic farms, chickpea plays an extremely important role in crop rotation because it have the ability to live in symbiosis with rhizobia that fix free atmospheric nitrogen [16]. The use of chickpeas in an organic farm is justified by its ability to fix atmospheric nitrogen.

Legume is characterized by high susceptibility to lodging, which adversely influenced seed yield and impedes harvesting with a harvester [17]. Intercropping with supporting plants can effectively reduce lodging of crops susceptible to it. A condition for using this cropping method is to select a species of supporting crop and its percentage in the mixture that will help reduce crop lodging. The aim of the study was to evaluate the effect of cropping method and botanical form on yielding and chemical composition of seeds of chickpeas grown under organic farming system.

\section{Materials and Methods}

\subsection{Field Experiment and Cultivation Management}

The experiment was conducted out in the years 2017-2018, at the Agricultural Experimental Station in Grabów [51 $21^{\prime} 18^{\prime \prime}$ N 21 $40^{\prime} 09^{\prime \prime}$ E] (Masovian Voivodeship, Poland). The experimental factors were as follows: (A) the types of chickpeas: kabuli and desi [5,6,18]; (B) cropping method: sole cropping (without a supporting crop) and row intercropping with barley (Hordeum vulgare L.- 'Ella' cultivar) and oat Avena sativa L. ('Bingo' cultivar). The experiment was set up as a split-plot design with four replicates, on a soil belonging to a very good rye complex, class IIIa. The soil was characterized by the following nutrient content: (mg.100 $\mathrm{kg}^{-1}$ soil): P 11.1-13.0; K 15.1-20.4 and Mg 4.0-6.2. Soil $\mathrm{pH}$, as determined in 1-N KCl, was 5.5-6.3. The previous crop of chickpeas was papilionaceous/grass mixture. The area of a single plot was $35 \mathrm{~m}^{2}$ and for harvest $-30 \mathrm{~m}^{-2}$. Each year the total number of plots in the experiment was 48 . The density (plants. $\mathrm{m}^{-2}$ ) of chickpeas in sole cropping was 100 , in row intercropping - 50; oat as supporting plant-250 and barley-150. Row spacing is $20 \mathrm{~cm}$. In both years of the study the chickpea seeds were sown in the first 10 days of May. Mineral fertilization was not applied. The plots were harrowed twice to control weeds in the mixtures. Plants were harvested at the full maturity stage of mixture components in the first 10 days of August. The plant height, the number of pods and seeds on the plant, the seat height of the first and last pod, the weight of seeds on the plant, the air dry weight of the stem of one plant and the weight of the pods were determined before harvest. The number and weight of grain per cereal plant, weight of 1000 grains and number of production 
shoots were also determined. The mixture and chickpea seed yield, component percentage in yield and 1000 -seed weight at $14 \%$ humidity were determined after harvest.

\subsection{Chemical Analysis of Chickpea Seeds}

The following were determined in seed chickpea samples: N, P (determination by the flow analysis (CFA) and spectrometric detection), $\mathrm{K}$ (determination by atomic emission spectroscopy (FES)). Moreover, total protein (mineralization in sulfuric acid; determination by the Kjeldahl distillation method), fat content (Soxhlet method) were also determined.

\subsection{Statistical Analysis}

Assessing the significance of the impact of the considered factors on the features was based on the variance analysis, indicating Tukey's confidence half-intervals at a significance level of 0.05 . The results were statistical analysis of variance using Statistica v.10.0 program.

\subsection{Weather Conditions}

During study period weather conditions varied substantially between the years (Figure 1). At the end of the second 10 days of April in 2017, there was a strong cool down, which prevented the sowing of cereal and chickpea. In 2017 the highest amount of rainfall was recorded in April, exceeded by $77 \%$ the multiyear period average. In June and the first 10 days of July, a small amount of rainfall was recorded. This was lower than the multiyear period average by $54.1 \%$ and $65.0 \%$, respectively. Very little rainfall also occurred at the first 10 days of August, which caused premature plant maturation. The average air temperature exceeded the long-term average by $1.4{ }^{\circ} \mathrm{C}$. In 2018 , the amount of rainfall in May and July exceeded the multiyear average by $70.9 \%$ and $41.1 \%$, respectively. During April and June, the total rainfall was only $65 \%$ and $63 \%$ of the multiyear period average, respectively. The average air temperature in this season exceeded the multiyear period average by $2.4^{\circ}$.

a)

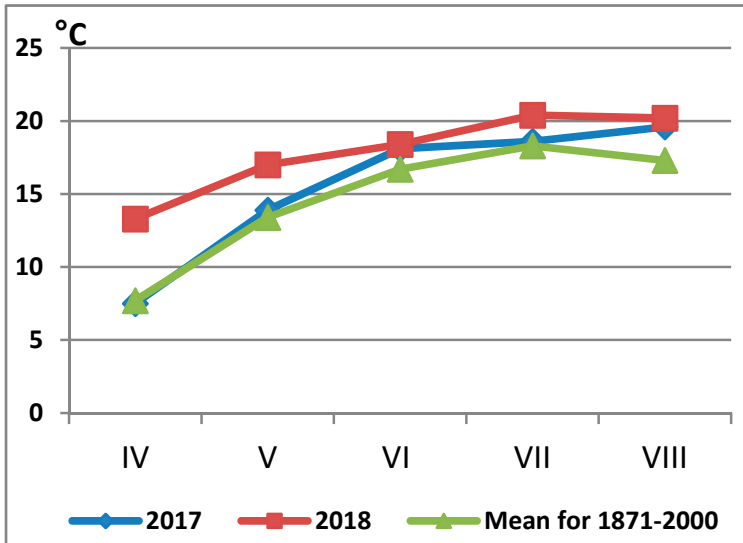

b)

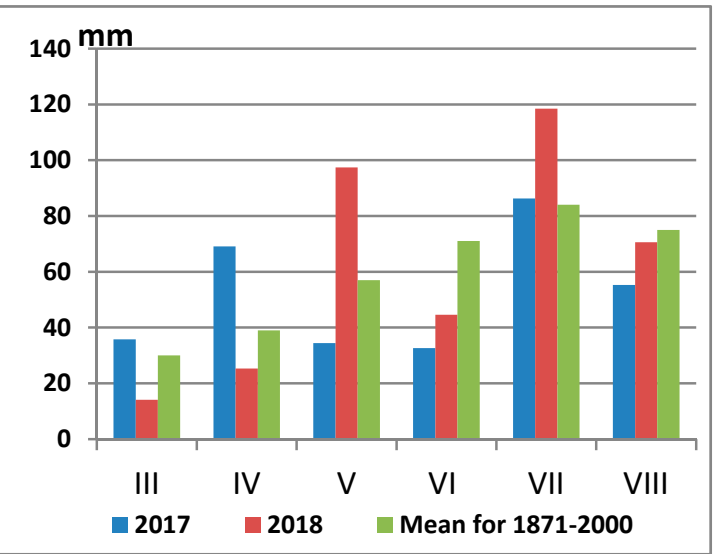

Figure 1. Course of weather conditions during vegetation season of the years 2017-2018. (a) Temperature and (b) precipitation.

\section{Results}

The cropping method, species of supporting crop and the course of weather conditions during the growing season significantly affected the yielding of both types of chickpeas (kabuli and desi) and their total yield with cereals. During the study period, 2018 had the most favorable weather conditions - higher amount of precipitation and its distribution, allowing to obtain higher total yields of all crop species tested in the study, compared with 2017 (Table 1). The higher yield obtained in 2018 was the result of a greater number of pods, number and weight of seeds of both botanical form of 
chickpeas and grains of barley and oat. In both years of the study, a higher total yield was achieved by growing chickpea with cereals compared to growing in sole cropping. The higher yield was found in the treatment where chickpeas were grown with oats as a supporting plant than with barley or in sole cropping (statistically significant differences). However, significantly better thousand-seed-weights of both botanical forms of chickpeas allowed growing of chickpeas in sole cropping than with supporting plants (significant differences) (Table 1). On average, in 2 years of the study, both in sole cropping and with cereals, desi chickpeas yielded better than the kabuli type, while in the drier year (2017) growing the kabuli chickpea form allowed obtaining higher yields (Table 2). There are relatively few studies on chickpeas grown under organic conditions, including agrotechnical factors and especially their cultivation with supporting crops.

Table 1. Total seed yields of chickpeas and supporting plant $\left(\mathrm{t} \cdot \mathrm{ha}^{-1}\right)$ and 1000 seed weights $(\mathrm{g})$, depending on cropping method and type (k-kabuli; $\mathrm{d}$-desi; ns—not significant at Tukey's test $P \leq 0.05)$.

\begin{tabular}{ccccccc}
\hline \multirow{2}{*}{ Cropping Method } & \multicolumn{3}{c}{ Seed Yields } & \multicolumn{3}{c}{ Thousand-Seed-Weights } \\
\cline { 2 - 7 } & $\mathbf{2 0 1 7}$ & $\mathbf{2 0 1 8}$ & Average & $\mathbf{2 0 1 7}$ & $\mathbf{2 0 1 8}$ & Average \\
\hline k-sole cropping & 0.56 & 2.20 & 1.38 & 231.0 & 328.6 & 279.8 \\
k + barley & 0.90 & 2.34 & 1.62 & 174.2 & 268.5 & 221.3 \\
k + oat & 1.40 & 2.64 & 2.02 & 173.8 & 265.1 & 219.4 \\
d-sole cropping & 0.49 & 2.51 & 1.50 & 124.8 & 213.2 & 169.0 \\
d + barley & 0.81 & 2.97 & 1.89 & 108.2 & 176.0 & 142.1 \\
d + oat & 1.34 & 3.00 & 2.17 & 106.4 & 170.1 & 138.3 \\
Average & 0.91 & 2.61 & - & 153.1 & 236.9 & - \\
LSD ( $\alpha=0.05):$ & & & & & & \\
Type (A) & 0.050 & 0.098 & 3.147 & 9.03 & $\mathrm{~ns}$ & \\
Cropping method (B) & 0.045 & 0.116 & 8.696 & 5.19 & 0.04 & - \\
B/A & $\mathrm{ns}$ & 0.164 & 12.298 & 7.34 & $\mathrm{~ns}$ & \\
A/B & $\mathrm{ns}$ & 0.140 & 8.574 & 9.80 & $\mathrm{~ns}$ & \\
\hline
\end{tabular}

Table 2. Share of chickpeas (\%) and seed yields ( $t \cdot \mathrm{ha}^{-1}$ ) depending on cropping method and type (k-kabuli; d-desi; ns-not significant at Tukey's test $P \leq 0.05$ ).

\begin{tabular}{|c|c|c|c|c|c|c|}
\hline \multirow{2}{*}{ Cropping Method } & \multicolumn{3}{|c|}{ Share of Chickpea } & \multicolumn{3}{|c|}{ Seed Yields of Chickpea } \\
\hline & 2017 & 2018 & Average & 2017 & 2018 & Average \\
\hline k-sole cropping & - & - & - & 0.56 & 2.20 & 1.38 \\
\hline k+ barley & 3.3 & 32.5 & 17.9 & 0.03 & 0.76 & 0.39 \\
\hline $\mathrm{k}+$ oat & 2.3 & 30.7 & 16.5 & 0.03 & 0.81 & 0.42 \\
\hline $\mathrm{d}$-sole cropping & - & - & - & 0.49 & 2.51 & 1.50 \\
\hline $\mathrm{d}+$ barley & 2.5 & 36.8 & 19.6 & 0.02 & 1.09 & 0.56 \\
\hline $\mathrm{d}+$ oat & 1.8 & 34.0 & 17.9 & 0.02 & 1.02 & 0.52 \\
\hline Average & 2.47 & 33.5 & - & 0.19 & 1.40 & - \\
\hline $\begin{array}{c}\text { LSD }(\alpha=0.05): \\
\text { Type }(\mathrm{A})\end{array}$ & & & & ns & 0.087 & \\
\hline $\begin{array}{c}\text { Cropping method (B) } \\
\text { B/A } \\
\text { A/B }\end{array}$ & - & - & - & $\begin{array}{l}0.040 \\
\text { ns } \\
\text { ns }\end{array}$ & $\begin{array}{c}0.106 \\
\text { ns } \\
\text { ns }\end{array}$ & - \\
\hline
\end{tabular}

The percentage of seed yields of type desi grown with supporting crop, regardless cereal species, was significantly lower than the kabuli type (Table 2). Moreover, oat was more competitive with chickpea than barley, resulting in a lower percentage of legume seeds in mixture with oat. The percentage in the seed yields of chickpeas grown with a supporting crop was much lower than when shown as sole crop, especially chickpeas grown with oat. The chickpeas grown in sole cropping was characterized higher the 1000 seed weight, number of pods, number and weight of seeds per plant and dry weight stem and siliques than those grown with supported crop (significant differences) (Tables 1 and 3-5). In the 
kabuli-type chickpeas regardless of the cropping method characterized higher the 1000 seed weight, seeds weight and number of pods per plant than type desi (Tables 2, 4 and 5).

Table 3. Number of pods per chickpea plant, depending on cropping method and type (k-kabuli; $\mathrm{d}-$ desi; ns-not significant at Tukey's test $P \leq 0.05$ ).

\begin{tabular}{cccc}
\hline \multirow{2}{*}{ Cropping Method } & \multicolumn{3}{c}{ Number of Pods Per Plant Chickpea } \\
\cline { 2 - 4 } & $\mathbf{2 0 1 7}$ & $\mathbf{2 0 1 8}$ & Average \\
\hline k-sole cropping & 3.11 & 5.10 & 4.10 \\
k + barley & 1.42 & 2.45 & 1.94 \\
k + oat & 1.31 & 1.90 & 1.60 \\
d-sole cropping & 2.80 & 6.20 & 4.50 \\
d + barley & 1.02 & 1.68 & 1.35 \\
d + oat & 0.98 & 1.20 & 1.09 \\
Average & 1.77 & 3.09 & - \\
\hline LSD ( $\alpha=0.05):$ & & & \\
Type (A) & 0.050 & 0.025 & - \\
Cropping method (B) & 0.056 & 0.036 & - \\
B/A & $n s$ & 0.051 & \\
A/B & $n s$ & 0.041 & \\
\hline
\end{tabular}

Table 4. Seed weight (g) and number per chickpea plant, depending on cropping method and type (k-kabuli; d-desi; ns-not significant at Tukey's test $P \leq 0.05$ ).

\begin{tabular}{ccccccc}
\hline \multirow{2}{*}{ Cropping Method } & \multicolumn{3}{c}{ Seeds Number Per Plant } & \multicolumn{3}{c}{ Seed Weight Per Plant } \\
\cline { 2 - 7 } & $\mathbf{2 0 1 7}$ & $\mathbf{2 0 1 8}$ & Average & $\mathbf{2 0 1 7}$ & $\mathbf{2 0 1 8}$ & Average \\
\hline k-sole cropping & 1.12 & 3.90 & 2.51 & 0.42 & 1.60 & 1.01 \\
k + barley & 0.61 & 2.10 & 1.36 & 0.31 & 0.56 & 0.43 \\
k + oat & 0.40 & 1.48 & 0.94 & 0.27 & 0.40 & 0.33 \\
d-sole cropping & 1.17 & 5.40 & 3.28 & 0.38 & 1.41 & 0.89 \\
d + barley & 0.54 & 1.55 & 1.04 & 0.22 & 0.22 & 0.22 \\
d + oat & 0.38 & 1.03 & 0.70 & 0.22 & 0.19 & 0.20 \\
Average & 0.70 & 2.58 & - & 0.30 & 0.73 & - \\
LSD ( $\alpha=0.05):$ & & & & & & \\
Type (A) & ns & 0.099 & & 0.008 & 0.083 & \\
Cropping method (B) & 0.780 & 0.130 & - & 0.007 & 0.043 & - \\
B/A & 0.100 & 0.184 & & 0.010 & 0.060 & \\
A/B & 0.100 & 0.151 & & 0.010 & 0.088 & \\
\hline
\end{tabular}

Table 5. Dry weight stem of one plant (g) and siliques (g), depending on cropping method and type (k-kabuli; d-desi; ns-not significant at Tukey's test $P \leq 0.05$ ).

\begin{tabular}{ccccccc}
\hline \multirow{2}{*}{ Cropping Method } & \multicolumn{3}{c}{ Stem Dry Matter of One Plant } & \multicolumn{3}{c}{ Dry Matter of Siliques } \\
\cline { 2 - 7 } & $\mathbf{2 0 1 7}$ & $\mathbf{2 0 1 8}$ & Average & $\mathbf{2 0 1 7}$ & $\mathbf{2 0 1 8}$ & Average \\
\hline k-sole cropping & 0.14 & 0.43 & 0.28 & 0.08 & 0.26 & 0.17 \\
k + barley & 0.08 & 0.16 & 0.12 & 0.04 & 0.10 & 0.07 \\
k + oat & 0.08 & 0.13 & 0.10 & 0.04 & 0.11 & 0.08 \\
d-sole cropping & 0.13 & 0.39 & 0.26 & 0.05 & 0.16 & 0.11 \\
d+ barley & 0.07 & 0.07 & 0.07 & 0.03 & 0.45 & 0.24 \\
d + oat & 0.07 & 0.06 & 0.06 & 0.03 & 0.50 & 0.26 \\
Average & 0.10 & 0.21 & & 0.05 & 0.26 & \\
\hline LSD ( $\alpha=0.05):$ & & & & & & \\
Type (A) & $\mathrm{ns}$ & 0.008 & & $\mathrm{~ns}$ & $\mathrm{~ns}$ & \\
Cropping method (B) & 0.21 & 0.015 & - & 0.015 & $\mathrm{~ns}$ & - \\
B/A & $\mathrm{ns}$ & 0.021 & & $\mathrm{~ns}$ & $\mathrm{~ns}$ & \\
A/B & $\mathrm{ns}$ & 0.016 & & $\mathrm{~ns}$ & $\mathrm{~ns}$ & \\
\hline
\end{tabular}


In own study the cropping method of chickpeas have effect on height to the first and the last pod, but have no effect on plant height (Table 6). Moreover, these properties also did not differentiate significantly the two assessed species.

Table 6. Height to the first pod, height to the last pod and height to top of chickpeas $(\mathrm{cm})$, depending cropping method and type (k-kabuli; $\mathrm{d}-\mathrm{desi})$.

\begin{tabular}{cccccccccc}
\hline \multirow{2}{*}{ Cropping Method } & \multicolumn{3}{c}{ Height to the 1st Pod } & \multicolumn{3}{c}{ Height to the Last Pod } & \multicolumn{3}{c}{ Plant Height } \\
\cline { 2 - 10 } & $\mathbf{2 0 1 7}$ & $\mathbf{2 0 1 8}$ & Average & $\mathbf{2 0 1 7}$ & $\mathbf{2 0 1 8}$ & Average & $\mathbf{2 0 1 7}$ & $\mathbf{2 0 1 8}$ & Average \\
\hline k一-sole cropping & 35.0 & 40.2 & 37.6 & 36.2 & 40.5 & 38.4 & 38.2 & 46.0 & 42.1 \\
k + barley & 36.1 & 42.4 & 39.3 & 36.9 & 43.0 & 40.0 & 38.9 & 47.0 & 42.9 \\
k + oat & 36.9 & 43.3 & 40.1 & 37.4 & 44.0 & 40.7 & 40.0 & 46.0 & 43.0 \\
d- - 0 c cropping & 33.2 & 38.4 & 35.8 & 34.2 & 38.9 & 36.6 & 36.8 & 44.1 & 40.4 \\
d + barley & 34.0 & 39.8 & 36.9 & 34.8 & 40.1 & 37.4 & 37.2 & 45.2 & 41.2 \\
d + oat & 34.8 & 40.7 & 37.8 & 35.3 & 40.9 & 38.1 & 37.7 & 45.9 & 41.8 \\
Average & 35.0 & 40.8 & - & 35.8 & 41.2 & - & 38.1 & 45.7 & - \\
\hline
\end{tabular}

Chemical composition in chickpea seeds depended on weather conditions during vegetation season of plants. The weather conditions of 2017 had beneficial effects on raising the concentration of protein, fiber and fat in chickpea seeds and had little effect on potassium and phosphorus content (Tables 7 and 8). Cropping method and botanical form of chickpeas had effects on protein and fat, phosphorus, but little on fiber content. The cropping method of chickpeas did not affect potassium and content (no significant differences) in seeds. Growing chickpeas as sole crops significantly reduced the seed content of chemical components compared to growing with supporting crops.

The highest content of protein and phosphorus-regardless of the cropping method-was determined in kabuli-type seeds while, in turn, the desi type was characterized by the highest content of fiber and fat. Moreover, both botanical forms of chickpea assessed were characterized by similar content of potassium, regardless of cropping method (Tables 7 and 8).

Table 7. Total protein, crude fiber and fat content $\left(\mathrm{g} \cdot \mathrm{kg}^{-1}\right)$ in chickpea seeds, depending cropping method and type (k-kabuli; $\mathrm{d}-$ desi; ns—not significant at Tukey's test $P \leq 0.05)$.

\begin{tabular}{ccccccccccc}
\hline & \multicolumn{9}{c}{ Chemical Composition } \\
\cline { 2 - 10 } Cropping Method & \multicolumn{3}{c}{ Protein } & \multicolumn{3}{c}{ Fat } & \multicolumn{3}{c}{ Fiber } \\
\cline { 2 - 11 } & $\mathbf{2 0 1 7}$ & $\mathbf{2 0 1 8}$ & Average & $\mathbf{2 0 1 7}$ & $\mathbf{2 0 1 8}$ & Average & $\mathbf{2 0 1 7}$ & $\mathbf{2 0 1 8}$ & Average \\
\hline k一 sole cropping & 262.5 & 251.1 & 256.8 & 54.2 & 53.8 & 54.0 & 51.8 & 42.9 & 47.4 \\
k + barley & 287.5 & 261.0 & 274.2 & 54.8 & 54.2 & 54.5 & 52.7 & 43.1 & 47.9 \\
k + oat & 287.5 & 264.2 & 275.8 & 55.3 & 53.8 & 54.6 & 52.4 & 43.9 & 48.1 \\
d-sole cropping & 206.3 & 198.0 & 202.2 & 57.0 & 56.1 & 56.6 & 52.2 & 43.8 & 48.0 \\
d + barley & 218.8 & 204.1 & 211.4 & 57.4 & 55.9 & 56.6 & 53.1 & 44.4 & 48.7 \\
d + oat & 237.5 & 205.0 & 221.2 & 56.2 & 56.4 & 56.3 & 53.4 & 44.9 & 49.1 \\
Average & 250.0 & 230.6 & - & 55.8 & 55.0 & - & 52.6 & 43.8 & - \\
\hline LSD ( $\alpha=0.05):$ & & & & & & & & & \\
Type (A) & 0.54 & 0.51 & & 0.17 & 0.42 & & 0.41 & 0.29 & \\
Crop method (B) & 0.42 & 0.38 & - & 0.24 & ns & - & 0.42 & 0.28 & - \\
B/A & 0.30 & 0.28 & & 0.34 & 0.29 & & ns & ns & \\
A/B & 0.28 & 0.20 & & 0.27 & 0.19 & & ns & ns & \\
\hline
\end{tabular}


Table 8. Concentrations of phosphorus and potassium $\left(\mathrm{g} \cdot \mathrm{kg}^{-1}\right)$ in chickpea seeds, depending on cropping method and type (k-kabuli; $\mathrm{d}-$ desi; ns—not significant at Tukey's test $P \leq 0.05)$.

\begin{tabular}{ccccccc}
\hline & \multicolumn{6}{c}{ Chemical Composition } \\
\cline { 2 - 7 } Cropping Method & \multicolumn{5}{c}{ Phosphorus } & \multicolumn{5}{c}{ Potassium } \\
\cline { 2 - 7 } & $\mathbf{2 0 1 7}$ & $\mathbf{2 0 1 8}$ & Average & $\mathbf{2 0 1 7}$ & $\mathbf{2 0 1 8}$ & Average \\
\hline k-sole cropping & 5.7 & 5.2 & 5.4 & 10.2 & 10.1 & 10.1 \\
k + barley & 6.3 & 5.8 & 6.1 & 10.3 & 9.4 & 9.9 \\
k + oat & 6.0 & 5.8 & 5.9 & 10.1 & 10.2 & 10.1 \\
d-sole cropping & 4.7 & 4.0 & 4.4 & 11.0 & 10.5 & 10.8 \\
d + barley & 4.4 & 4.2 & 4.3 & 12.1 & 11.2 & 11.6 \\
d + oat & 4.5 & 4.2 & 4.4 & 11.3 & 11.1 & 11.2 \\
Average & 5.2 & 4.9 & - & 10.8 & 10.4 & - \\
LSD ( $\alpha=0.05):$ & & & & & & \\
Type (A) & 0.25 & 0.27 & & $\mathrm{~ns}$ & $\mathrm{~ns}$ & \\
Cropping method (B) & 0.09 & 0.17 & - & $\mathrm{ns}$ & $\mathrm{ns}$ & - \\
B/A & 0.13 & 0.24 & & $\mathrm{~ns}$ & $\mathrm{~ns}$ & \\
A/B & 0.09 & 0.30 & & $\mathrm{~ns}$ & $\mathrm{~ns}$ & \\
\hline
\end{tabular}

Regardless of form, chickpea relatively weakly affected the height of barley and oats, the number of grains per plant and the number of producing shoots, 1000 seed weights of both cereal species included in the experiments (Tables 9 and 10). In addition, both cereal species grown with chickpea form desi characterized a better weight of grain on the plant.

Table 9. Number, weight of cereal grains per plant (g) and thousand grain weight (g) of cereals depending on method sowing depending on type (k-kabuli; $d$-desi; ns-not significant at Tukey's test $P \leq 0.05)$.

\begin{tabular}{|c|c|c|c|c|c|c|c|c|c|}
\hline \multirow{2}{*}{ Cropping Method } & \multicolumn{3}{|c|}{$\begin{array}{c}\text { Number of Grain Per } \\
\text { Plant }\end{array}$} & \multicolumn{3}{|c|}{$\begin{array}{c}\text { Weight of Grain Per } \\
\text { Plant }\end{array}$} & \multicolumn{3}{|c|}{$\begin{array}{c}\text { Thousand Grain } \\
\text { Weight }\end{array}$} \\
\hline & 2017 & 2018 & Average & 2017 & 2018 & Average & 2017 & 2018 & Average \\
\hline $\mathrm{k}+$ barley & 32.1 & 36.9 & 34.5 & 1.04 & 1.49 & 1.26 & 36.8 & 42.4 & 39.6 \\
\hline$d+$ barley & 32.4 & 38.0 & 35.2 & 1.06 & 1.68 & 1.37 & 37.2 & 43.5 & 40.3 \\
\hline $\mathrm{k}+$ oat & 61.0 & 63.9 & 62.4 & 1.08 & 1.77 & 1.43 & 26.4 & 30.6 & 28.5 \\
\hline $\mathrm{d}+$ oat & 60.9 & 62.9 & 61.9 & 1.07 & 1.97 & 1.52 & 27.0 & 29.9 & 28.4 \\
\hline Average & 46.6 & 50.4 & - & 1.06 & 1.73 & - & 31.8 & 36.6 & - \\
\hline \multicolumn{10}{|l|}{$\operatorname{LSD}(\alpha=0.05)$} \\
\hline Type (A) & 9.94 & 0.19 & & 0.025 & 0.143 & & 1.74 & 3.62 & \\
\hline Cropping method (B) & $\mathrm{ns}$ & ns & _ & ns & 0.086 & _ & $\mathrm{ns}$ & ns & _ \\
\hline B/A & ns & 0.36 & & ns & ns & & ns & 0.97 & \\
\hline $\mathrm{A} / \mathrm{B}$ & ns & 0.31 & & ns & ns & & ns & 3.67 & \\
\hline
\end{tabular}

Table 10. Height plant $(\mathrm{cm})$ and number of producing shoots of cereals depending on type (k-kabuli; d-desi).

\begin{tabular}{ccccccc}
\hline \multirow{2}{*}{ Cropping Method } & \multicolumn{3}{c}{ Height Plant } & \multicolumn{3}{c}{ Number of Producing Shoots } \\
\cline { 2 - 7 } & $\mathbf{2 0 1 7}$ & $\mathbf{2 0 1 8}$ & Average & $\mathbf{2 0 1 7}$ & $\mathbf{2 0 1 8}$ & Average \\
\hline k + barley & 37.4 & 41.4 & 39.4 & 2.68 & 3.29 & 2.98 \\
d+ barley & 38.1 & 46.6 & 42.4 & 2.93 & 3.22 & 3.07 \\
k + oat & 53.4 & 58.0 & 55.7 & 2.03 & 2.09 & 2.06 \\
d + oat & 55.0 & 62.4 & 58.7 & 1.95 & 2.10 & 2.03 \\
Average & 46.0 & 52.1 & - & 2.40 & 2.67 & - \\
\hline
\end{tabular}




\section{Discussion}

The current study showed that the cropping method, species of supporting crop and course of weather conditions during the growing season significantly affected the yields of both types of chickpeas and their total yield with cereals.

There are relatively few studies on chickpeas grown under organic conditions-including agrotechnical factors and especially their cultivation with supporting crops. Kaczmarek-Cichosz [19] reported that chickpea seed yield is inversely proportional to the sum of precipitation during the growing season - especially during emergence and ripening of pods. This author [19] and Poniedziałek et al. [20] also found a relationship between yield and environmental factors, such as precipitation and temperature. In addition, they also report that-along with the increase in the sum of effective temperatures during the growing season-they observed a tendency of higher temperatures to increase yield, while its reduction may be affected by the amount of precipitation during flowering and setting pods. Frimpong et al. [10] found that kabuli varieties had lower seed yield compared with desi varieties. For desi varieties, mean seed yield across varieties and environments was $1462 \mathrm{~kg} \cdot \mathrm{ha}^{-1}$ and mean thousand-seed weight was $228 \mathrm{~g}$. While Skowera et al. [21] emphasize that the number of days with precipitation in July and August is important, a large number of such days-when chickpeas set up pods and reach full maturity-may be a hindrance to the cultivation of this species. Moreover, according to these authors, with low precipitation, this species may produce high- and good-quality crops, compared to those recorded by Singh et al. [22] in southern Europe. However, according to Gunes et al. [23] drought occurring during all development phases of this species is the main or a key factor that limits its yield the most-which results from the decrease in soil humidity [24]. Skowera et al. [21] observed a positive correlation between seed yield and the sum of precipitation in the period from emergence to setting pods, as well as a negative correlation between the seed yield and the amount of precipitation during the maturing period of the pods. Kaczmarek-Cichosz [19] recorded a similar level of yielding in chickpeas grown on light soil with a granulometric composition of loamy sand and grown on medium soil with a granulometric composition of light clay. This author recorded an approximately $75 \%$ higher seed yield in the year with more favorable precipitation than in the year unfavorable for cultivating this species. Özdemir and Karadavut [25] reported that the average yield of 21 spring chickpeas varied from 1.0 to $2.1 \mathrm{t} \cdot \mathrm{ha}^{-1}$ and winter forms were twice as high. Księżak and Bojarszczuk [26] recorded a much higher yield of grass peas grown with a supporting crop (by 11.4\%) than in sole cropping. Özdemir and Karadavut [25] indicated that the winter chickpea plants in Turkey—characterized by higher height than spring forms $(56.0-61.1 \mathrm{~cm})$-formed from 17.0 to 17.7 pods per plant, and the 1000-seed weight ranged from 340 to $369 \mathrm{~g}$. Lykhochvor and Pushchak [27] noted the beneficial effects of mineral fertilization on the number of pods and weight of seed per plant, the number of seeds in the pod and the thousand-seed-weights, although the differences were not statistically significant. However, Kaczmarek-Cichosz [19], did not investigate the effect of type of soil on thousandseedweight. However, the author found a 3-times increase of thousand-seed-weights in a year with favorable weather conditions, as compared to a less favorable year.

Maheri-Sis et al. [28] recorded lower protein content and higher fiber content in desi seeds than kabuli seeds. Lykhchvor and Pushchak [27] reported that mineral fertilization has a positive effect on the content of protein, fat and fiber and reduces the amount of ash in chickpea seeds. Dziamba et al. [29] noted a significant diversity of the most important nutrients and some macroelements in several chickpea varieties cultivated in the Lublin region. In contrast, Skowera et al. [21] observed a negative correlation between protein content in chickpea seeds with the amount of precipitation during the flowering and setting of pods and a positive correlation between the amount of precipitation during the ripening period and protein content. Frimpong et al. [10] found that the kabuli varieties had an average of $186 \mathrm{~g} \cdot \mathrm{kg}^{-1}$ protein, which is slightly lower as compared with desi varieties. Those authors also found that protein concentration and seed yield were negatively correlated $(r=-0.19, P=0.01)$ in desi, but not in kabuli ( $r=-0.06$, ns). Moreover, no correlation was observed between protein concentration and seed weight in desi $(r=0.04, \mathrm{~ns})$ and kabuli $(r=-0.02, \mathrm{~ns})$ chickpeas. They found 
significant positive interaction between the genotype and environment for starch, amylose and protein (except for kabuli) concentrations, seed yield and seed weight.

\section{Conclusions}

The highest total seed yields of both forms of chickpeas grown in pure-sowing and with supporting crops was obtained in the year with more favorable weather conditions (2018). Higher yields in this year were the result of a greater number of pods, seeds number, seed weight on each plant and the grain weight of cereals.

Higher total yields were noted in chickpeas grown with supporting crops than in sole cropping. Significantly better thousand-seed-weights of both botanical forms of chickpeas allowed growing of chickpeas in sole cropping than with supporting plants.

The type desi grown as sole cropping as with supporting crops characterized by higher yields than the type kabuli and its percentage in seed yields of chickpeas grown with cereals was higher than in the kabuli type.

Neither form of chickpea had a significant effect on the cereal plant height, number of grains on plant and number of producing shoots nor thousand grain weight of barley and oats. Regardless of the cropping method, the highest content of fiber and fat was determined in desi-type seeds. The highest protein and phosphorus was characterized kabuli-type seeds.

In summary, one condition for using this cropping method is to select a supporting crop and its proportion in the mixture that will help reduce crop lodging, while in the case of low chickpea yield, the supporting component largely decreases the risk of total yield loss.

Author Contributions: J.K. Conceptualization the research; J.K. methodology; J.K. performance the experiment; J.K., J.B. analysis of data; J.K., J.B. writing — original draft preparation. All authors have read and agreed to the published version of the manuscript.

Funding: This research received no external funding.

Conflicts of Interest: The authors declare no conflict of interest. The funders had no role in the design of the study; in the collection, analyses or interpretation of data; in the writing of the manuscript or in the decision to publish the results.

\section{References}

1. Merga, B.; Haji, J. Economic importance of chickpea: Production, value, and world trade. Cogent Food Agric. 2019, 5, 1615718. [CrossRef]

2. Food and Agriculture Organization (FAO). FAOSTAT Statistical Database of the United Nation Food and Agriculture Organization (FAO) Statistical Division; FAO: Rome, Italy, 2019. Available online: http://www.fao. org/statistics/en/ (accessed on 15 March 2020).

3. Berger, J.; Abbo, S.; Tuner, N.C. Ecogeography of annual wild cicer species. Crop Sci. 2003, 43, 1067-1090. [CrossRef]

4. Kumar, J.; Abbo, S. Genetics of flowering time in chickpea and its bearing on productivity in semi-arid environments. Adv. Agron. 2001, 72, 107-138.

5. Iqbal, A.; Ateeq, N.; Khalil, I.A.; Perveen, S.; Saleemullah, S. Physicochemical characteristics and amino acid profile of chickpea cultivars grown in Pakistan. J. Foodserv. 2006, 17, 94-101. [CrossRef]

6. Naghavi, M.R.; Jahansouz, M.R. Variation in the agronomic and morphological traits chickpea accessions. J. Integr. Plant Biol. 2005, 47, 375-379. [CrossRef]

7. Viveros, A.; Brenes, A.; Elices, R.; Arija, I.; Canales, R. Nutritional value of raw and autoclaved kabuli and desi chickpea (Cicer arietinum L.) for growing chickpea. Br. Poult. Sci. 2001, 42, 242-251. [CrossRef]

8. Moreno, M.; Cubero, J.I. Variation in Cicer arietinum L. Euphytica 1978, 27, 465-485. [CrossRef]

9. Pande, S.; Siddique, K.H.M.; Kishore, G.K.; Bayaa, B.; Gaur, P.M.; Gowda, C.L.L.; Bretag, T.W.; Crouch, J.H. Ascochyta blight of chickpea: Biology, pathogenicity, and disease management. Aust. J. Agric. Res. 2005, 56, 317-332. [CrossRef] 
10. Frimpong, A.; Sinha, A.; Tar'an, B.; Warkentin, T.D.; Gossen, B.D.; Chibbar, R.N. Genotype and growing environment influence chickpea (Cicer arientinum L.) seed composition. J. Sci. Food Agric. 2009, 89, 2052-2063. [CrossRef]

11. Wood, J.A.; Grusak, M.A. Nutritional value of chickpea. In Chickpea Breeding and Management; Yadav, S.S., Redden, R., Chen, W., Sharma, B., Eds.; CAB International: Wallingford, UK, 2007; pp. 101-142. [CrossRef]

12. Lampart-Szczapa, E. Legume seeds in human nutrition: Biology and technological value. (Rośliny strączkowe w żywieniu człowieka, wartość biologiczna i technologiczna). Zesz. Postępów Post. Nauk Rol. AR Poznań 1997, 446, 61-81. (In Polish)

13. Ohr, L.M. The latest scoop on soy. Food Technol. 2003, 8, 87-91.

14. Chibbar, R.N.; Ambigaipalan, P.; Hoover, R. Molecular diversity in pulse seed starch and complex carbohydrates and its role in human nutrition and health. Cereal Chem. 2010, 87, 342-352. [CrossRef]

15. Rincón, F.; Martínez, B.; Ibáñez, M.V. Proximate composition and antinutritive substancesin chickpea (Cicer arietinum L.) as affected by the biotype factor. J. Sci. Food Agric. 1998, 78, 382-388. [CrossRef]

16. Pociejowska, M.; Natywa, M.; Selwet, M. Praktyczne aspekty biologicznego wiązania azotu atmosferycznego. Wieś Jutra 2013, 174, 55-56. (In Polish)

17. Zawieja, J. Response of lentil (Lens culinaris Medic.) on intercropping with cereals as affected by rates and sowing dates. Part I. Biometrical traits and weed infestation. Zesz. Nauk. Uniw. Przyr. Wroctawiu Rol. 2006, 89, 377-386.

18. Muehlbauer, F.J. Food and grain legumes. In New Crops; Wiley: New York, NY, USA, 1993; pp. $256-265$.

19. Kaczmarek-Cichosz, R. Chickpea (Cicer arietinum L.)-The possibilities of crop in ecological farms in the region of the Middle Pomeranian (Ciecierzyca pospolita (Cicer arietinum L.) możliwości jej uprawy w gospodarstwach ekologicznych rejonu środkowopomorskiego). J. Res. Appl. Agric. Eng. 2009, 54, 115-118. (In Polish)

20. Poniedziałek, M.; Sękara, A.; Jędrszczyk, E.; Dziamba, S. Impact of location and sowing date on the amount and quality of two chickpea varieties (Cicer arietinum L.). (Wpływ lokalizacji i terminu uprawy na plony $\mathrm{i}$ jakość nasion dwóch odmian ciecierzycy pospolitej (Cicer arietinum L.)). Folia Univ. Agric. Stetin. Agric. 2004, 239, 319-324.

21. Skowera, B.; Sękara, A.; Jędraszczyk, E.; Poniedziałek, M.; Dziamba, S. Influence of meteorological conditions on the vegetation course of chickpea (Cicer arietinum L.) (Wpływ warunków meteorologicznych na przebieg wegetacji ciecierzycy pospolitej (Cicer arietinum L.)). Acta Agrophys. 2007, 9, 767-782.

22. Singh, K.B.; Omar, M.C.; Johannes, C. Screening for drought resistance in spring chickpea in the Mediterranean region. J. Agron. Crop. Sci. 1997, 178, 227-235. [CrossRef]

23. Gunes, A.; Inal, A.; Adak, M.S.; Bagci, E.G.; Cicek, N.; Araslan, F. Effect of drought stress implemented at pre-or post-anthesis stage on some physiological parameters as screening criteria in chickpea cultivars. J. Plant Physiol. 2008, 55, 59-67. [CrossRef]

24. Canci, H.; Toker, C. Evaluation of yield criteria for drought and heat resistance in chickpea (Cicer arietinum L.). J. Agron. Crop Sci. 2009, 195, 47-54. [CrossRef]

25. Özdemir, S.; Karadavut, U. Comparison of the performance of autumn and spring sowing of chickpeas in a temperate region. Turk. J. Agric. For. 2003, 27, 345-352.

26. Księżak, J.; Bojarszczuk, J. The effect of sowing method on the yield of grasspea (Lathyrus sativus) cultivated in an organic system. Appl. Ecol. Environ. Res. 2020, in press.

27. Lykhochvor, V.; Pushchak, V. The effect of varied fertilization on the yield and chemical composition of chickpea seed (Cicer arietinum L.). Pol. J. Sust. Devel. 2019, 23. [CrossRef]

28. Maheri-Sis, A.; Chamani, M.; Sadeghi, A.-A.; Mirza-Aghazadeh, A.; Aghajanzadeh-Golshani, A. Nutritional evaluation of kabuli and desi type chickpeas (Cicer arietinum L.) for ruminants using in vitro gas production technique. Afr. J. Biotech. 2008, 7, 2946-2951.

29. Dziamba, S.; Cebula, M.; Jackowska, I.; Maj, L.; Wielgo, B. Comparison of chemical composition of selected leguminous seeds (Porównanie składu chemicznego nasion wybranych roślin strączkowych). Zesz. Probl. Postepow Nauk Rol. 1999, 468, 117-126. (In Polish)

(C) 2020 by the authors. Licensee MDPI, Basel, Switzerland. This article is an open access article distributed under the terms and conditions of the Creative Commons Attribution (CC BY) license (http://creativecommons.org/licenses/by/4.0/). 